\title{
Demographic Pressure and Development in a Gender Perspective: A focus on sub-Saharan Africa
}

\author{
Fausta Ongaro ${ }^{1}$ and Silvana Salvini ${ }^{2}$
}

\author{
${ }^{1}$ Dipartimento di Scienze Statistiche, Università di Padova - Italy
}

fausta.ongaro@unipd.it

Dipartimento di Statistica, Informatica, Applicazioni "G.Parenti”, Università di Firenze -Italy

\begin{abstract}
High fertility and demographic pressure - combined with lack of gender equality and women's empowerment - may put in doubt development. The aim of our analysis is to study the role played by both the demographic pressure and social behavior on the Human Development Index (HDI) in the sub-Saharan Africa. After analyzing the territorial variability of $\mathrm{HDI}$ among and into some countries at district level in years around 1990, 2000 and 2010, we intend to understand if there is some form of association between Municipal Human Development Index and some indicators of socio-demographic structure.The hypothesis we want to verify is that the higher the level of demographic pressure (expressed by dependency ratios) and the worse the social context, the lower the level of development, according to the approach of "demographic window". This study enriches the literature by exploring the effect of the demographic window of opportunity on economic growth at district level within some countries of sub-Saharan Africa, in relationship with some indicators of women's status and gender equality as proxies of women's empowerment. Our results demonstrate a negative effect of the dependent population (young and old people) and a positive effect of indices of women's empowerment on development. In the model explaining the relation between development, dependency ratios and women's empowerment at local level, the inclusion of the dummies of the countries does not change the effects of the covariates, thus suggesting that the former relationships are not mediated through the country-time variables.
\end{abstract}

\section{Introduction}

Recently a large debate on the socio-economic opportunities offered by "demographic window" opened (Bloom et. al., 2003). The term demographic window defines a time interval, more or less extended, in which the age structure of a population is such that the ratio between demographically dependent people (the sum of under-15s and over$65 \mathrm{~s}$ aged persons) and the demographically independent people (15-64) is lower than the level that results in the other periods. In other words, in this time interval, the demographic pressure is the lowest we can find in the history of a country. Demographic pressure looks at the number of people but also at the structure of population, due to population components (mortality and fertility) that may influence economic development (Bloom, Canning and Malaney, 2000; Nugent and Seligman, 2008; Lutz, Sanderson and Scherbov, 2008; Hammer and Prskawetz and Freund, 2015; Sanderson and Scherbov, 20I5).

From a strictly demographic point of view, this period represents the "bridge" between a young and less developed population and an older and more developed population (low fertility and mortality) (Golini, 2004; van der Ven and Smits, 20I I)'. In this period of demographic window, it realizes the demographic dividend that is a rise in the rate of economic growth due to an increasing share of the working age population (Haghshenas et al., 2007; Saritha and Chandrashekara, 2014)2.

Among the background factors leading to demographic transition, women's empowerment is

\footnotetext{
1 This process induces a population bulge in the working age category. It occurs when a falling birth rate changes the age distribution of a population so that fewer investments are needed to meet the necessities of the youngest age groups and resources are released for investment in economic development and family welfare.

${ }^{2} \mathrm{UN}$ population department has defined the demographic window as the period of opportunity "when the proportion of children and youth under 15 years falls below $30 \%$ and the proportion of the people 65 years and older is still below 15\%". Typically, the demographic windows of opportunity last for 30-40 years depending upon the country (Roy and Roy, 2014).
} 
one of the most relevant ${ }^{3}$. It refers both to the process of self-empowerment and to professional support of women, which enables them to overcome their sense of powerlessness and lack of influence, and to recognize and eventually use their resources and chances. Empowering women to participate fully in economic life across all sectors is essential to build stronger economies, achieve internationally agreed goals for development and sustainability, and improve the quality of life for women, men, families and communities (OECD, 20I2). Women's economic empowerment is a prerequisite for sustainable development and pro-poor growth (OECD, 20I I).

Despite solid evidence demonstrating the centrality of women's empowerment to reducing poverty, promoting development and addressing the world's most urgent challenges, gender equality remains an unfulfilled promise. For more than 30 years, UNFPA has advocated for women and girls, promoting legal and policy reforms and gendersensitive data collection, and supporting initiatives that improve women's health and expand their choices in life (see more at http://www.unfpa.org/genderequality\#sthash.Pps014 Yh.dpuf and http://www.unfpa.org/gender-equality).

Women empowerment and economic development are closely related: in one direction, development alone can play a major role in driving down inequality between men and women; in the other direction, empowering women may benefit development. Does this imply that pushing just one of these two levers would set a virtuous circle in motion (Duflo, 20/2)? Investing in women's economic empowerment sets a direct path towards gender equality, poverty eradication and inclusive economic growth. Women make enormous contributions to economies, whether in businesses, on farms, as entrepreneurs or employees, or by doing unpaid care work at home. (http://www.unwomen.org/en/whatwe-do/economic-empowerment (see more in http://www.unwomen.org/en/what-we-do/ economic-empowerment\#sthash.e3×2P576.dpuf and Swartz, 20/2).

Demographic and social factors affect the economic development of every country through a series of intermediate variables and in a multidimensional way (Nugent and Seligman, 2008; Madsen et al., 20I2).

\footnotetext{
${ }^{3}$ Empowerment refers to policies and measures designed to increase the degree of autonomy and self-determination in the lives of people and in communities in order to (re)enable them to represent their interests in a responsible and self-determined way, acting (again) on their own authority.
}

Firstly, dimension and age structure of population represent variables conditioning, for example, labor market, health services, schooling and pensions (Ebenstein, 2014). Consequently, the higher the number of young and old people the higher the related financial costs and the lower the budget of productive investments. We must take into account that the population structure depends on fertility, mortality and migration patterns, and may be affected by several variables interacting with these processes (Agwanda and Amani, 20I4). Among these variables, there is woman's status. Improvement of the condition of women tends to diminish fertility through education and entry into the labor market (even if in developing countries labor has a different meaning and different characteristics with respect to rich countries), that in turn impact on contraception and age at marriage. Therefore, we observe some mechanisms connecting the structure by age of population with female empowerment. We can outline two types of hypothesis: the first that relates directly development and age structure or that passes through woman's status; the second that there exist direct effects of both factors, i.e. age structure and female empowerment.

There is a third aspect that emerge in analyzing factors of development: the territorial context. Countries are generally not homogeneous from the point of view both of demographic components and of socio-economic conditions. Consequently, the local characteristics are fundamental for analyzing.

The knowledge of characteristics of sub-regions and municipalities helps us to interpret the relationships among age population structure and gender variables on one side and socio-economic development on the other (Rodriguez-Pose and Tijmistra, 2005). The importance of local level research is demonstrated also by the approach called LED (Local Economic Development) that focuses on the implementation of strategies referring to the use of local resources with the final aim of creating sustainable economic activities ${ }^{4}$.

To our knowledge, all these aspects are not generally jointly analyzed, while the aim of our

\footnotetext{
4 Local Economic Development is a strategy for employment promotion through micro and small enterprise development, support of social dialogue and development planning. At the center of the approach is the creation of public-private partnerships that bring together stakeholders in the local economy, including representatives of regional and local government, employers' and workers' organizations, Chambers of Commerce, cooperatives, producers' associations, women organizations and other NGOs (http://www.ilo.org/public/english/region/afpro/abidjan/pub l/ilo9/decent6.pdf).
} 
research carried out at municipality level is to consider the connection of development with demographic pressure and women empowerment. Firstly, we intend to study the role played by the demographic pressure - measured in particular by the dependency ratios at the base of the definition of demographic window - on the Human Development Index (HDI) in the sub-Saharan Africa. After analyzing the territorial variability of $\mathrm{HDI}$ among and into the countries belonging to sub-Saharan Africa, we intend to understand if there is some form of association between HDI and the indicators of demographic structure during the process of demographic transition. Secondly, we want to evaluate the role of woman's status and gender inequality on the process of development, measuring women's empowerment under different dimensions. Therefore, the core of our work is the analysis of the association between the structure of population (and consequently the demographic window), the gender variables and the development at a local level measured by Municipality Human Development Index (MHDI). The hypothesis we want to verify is that the higher the level of demographic pressure (that is the level of dependency ratios), the lower the level of development. On the other side, we want to verify that the higher the level of female empowerment, the higher is the level of territorial development, due to the commitment women put on the valorization of human capital and improvement of family status. In order to do this we used at municipality level the Census data of some countries of sub-Saharan Africa included in the database called IPUMS (https://international.ipums.org/internationalaction/users/login).

\section{Demographic transition and demographic window in sub-Saharan Africa}

The demographic issue, and the multiple relationships between the rapid growth of the world population and the development, have been at the center of international debate since World War II onwards (UN, 2005). It was spreading a deep concern for the consequences of an unprecedented growth in the history of humankind (Bongaarts, 2009). The lack of birth control, especially in sub-Saharan Africa (Tabutin and Schoumaker, 2004), produced too numerous generations, frustrating attempts to improve education; led into the labor market newcomers into unemployment; forced women in household activities; produced uncontrollable migration to the cities (Livi Bacci, 20I4). In sum, high fertility and high level of population growth combined with lack of gender equality and women's empowerment - may put in doubt development (Ekane, 20I3).

By 2035, the number of sub-Saharan Africans reaching working age (15-64) will exceed that of the rest of the world combined (Figure I). For the region, the implications of current trends include a rapid increase in population and a delay in demographic transition and, consequently, a strong delay of the moment in which we will find the peak of the share of working age population identifying demographic window.

For the last several decades, the global working age population has been expanding at a rapid pace, supporting higher global growth. Nevertheless, more recently, this trend has started to reverse. On current trends, the world's working age population, excluding that of sub-Saharan Africa, will start to decline by 2050 or so. With aging populations elsewhere, sub-Saharan Africa could drive global population growth in the future (Wakeman-Linn et al., 20I5).

Sub-Saharan Africa can benefit from a significant opportunity related to the demographic window (that nowadays appears relatively far), but its distance in the future will depend on the speed of transition and policy choices. We must underline that the overall magnitude of the dividend does depend on many factors beyond the speed of fertility and infant mortality decline (Caldwell and Caldwell, 1993), to include rates of job creation, human capital development and improved political governance. To maximize the opportunity, sub-Saharan Africa will have to create high-productivity jobs at an average of about 18 million jobs per year until 2035 - an extremely rapid and possibly unprecedented rate to absorb the new entrants in the labor force. It will also require policies to be in place that encourage a gradual transition from the informal sector, which currently accounts for about 90 percent of the 400 million jobs in low-income sub-Saharan African countries, to non-agricultural formal sector employment. Failure to create sufficient jobs could result in severe economic and social problems. 
Figure I - Change (between time t-5 and t) in working age population (age 15-64): 1950-2100.

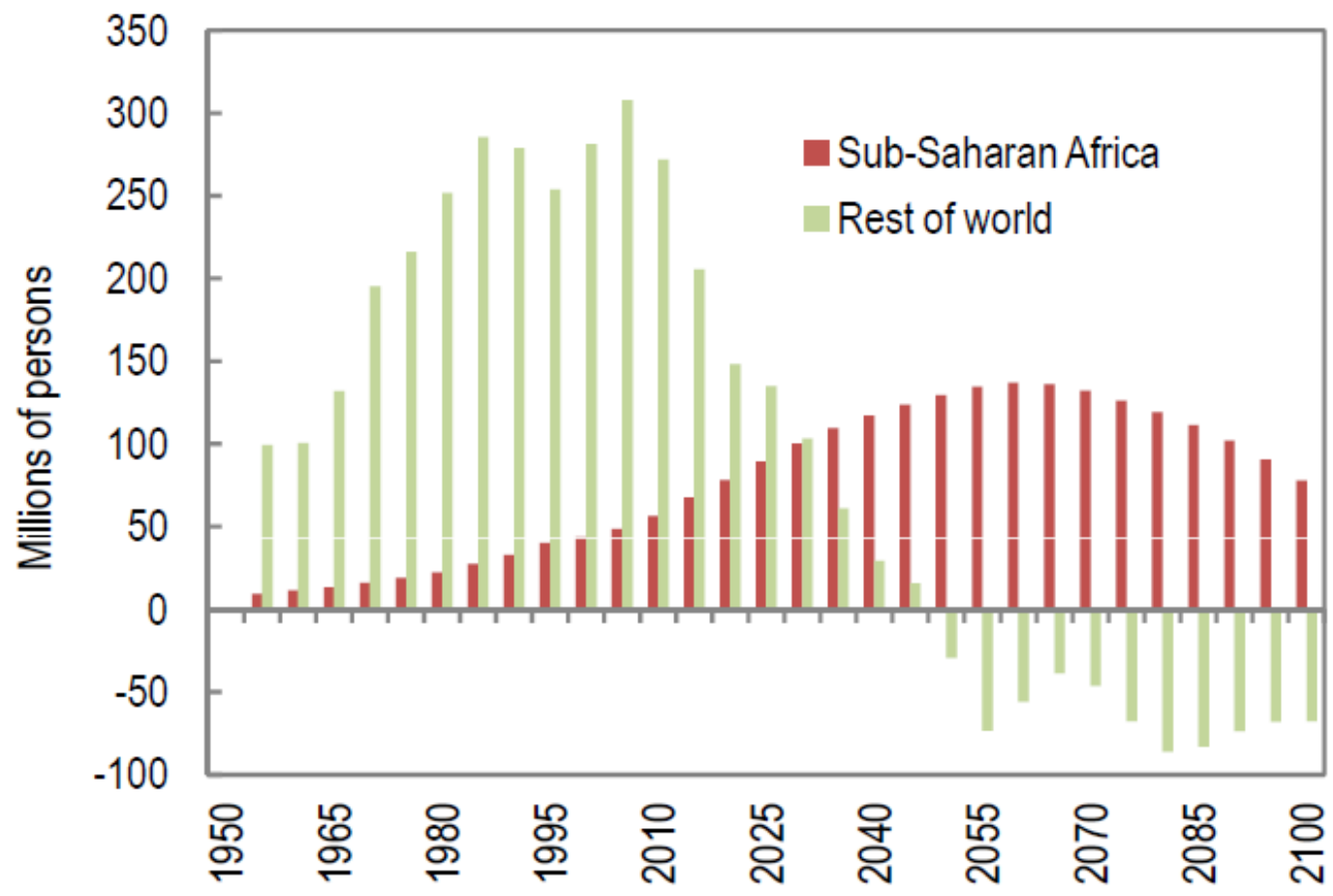

Sources: How Can Sub-Saharan Africa Harness the Demographic Dividend? Wakeman-Linn et al., in https://www.imf.org/external/pubs/ft/reo/20I5/afr/eng/pdf/chap2.pdf.

In recent years, an increasing number of African people are being added every year. This was not always the case these population increases are unprecedented in history. However, the problem of population is not simply a problem of numbers. It is a problem of human welfare and of development. Rapid population growth can have serious consequences for the well-being of humanity worldwide. If development entails the improvement in people's level of living - their income, health, education and general well-being - then the really important question about population growth is: how does the contemporary population situation in many African countries contribute to or detract from their chances of realizing the goals of development, not only for the current but also for the future generations (OAU and ECA, 20I0)? Conversely, how does development affect population growth? In conclusion, there is no doubt that the population problem in Africa is real and challenging. The impact of the effect of high birth and death rates, increasing population size and density, rapid population growth, and increasing dependency burden all translate into greater demands on the African governments in productive activities which in turn accentuate the problems of unemployment, underemployment, persistent poverty, urban slums, crime and political unrest (UN, 2008).

Failure to speed up the transition will delay the demographic window. Factors that matter for growth - for example, macroeconomic stability, trade openness, and strong institutions - also matter for harnessing a demographic opportunity, but take on greater importance in the face of rapidly growing populations and increasing shares of working age population. Some policies, however, become relatively more important in the context of the demographic transition (Wakeman-Linn et al., 2015).

Together with a pre-transitional age structure in sub-Saharan Africa due to high fertility level, we observe the highest level of social and economic hardship in the world. In fact, fertility in sub-Saharan Africa stood at 5.1 births per woman in 2005-10, more than double the replacement level. This high fertility combined with declining mortality has resulted in rapid population growth -2.5 percent per year - and the UN projects the sub-Saharan population to grow from 0.86 billion in 2010 to 1.96 billion in 2050 and 3.36 billion in 2100 . Such unprecedented expansion of human numbers creates a range of social, economic, and environmental challenges and makes it more difficult for the continent to raise living standards. Hence the growing interest in demographic trends in Africa among policymakers.

According to conventional demographic theory, high fertility in the early stages of the demographic transition is the consequence of high desired family size. Couples want many children to assist with family enterprises such as farming and for security in old 
age. In addition, high child mortality leads parents to have additional children to protect against loss or to replace losses. Fertility decline occurs once rising levels of urbanization and education, changes in the economy, and declining mortality lead parents to desire a smaller number of births. To implement these desires, parents rely on contraception or abortion, and family planning

programs in many countries accelerate their adoption (Bongaarts and Casterline, 20I3).

The pace and path of the demographic transition varies greatly across sub-Saharan Africa (Madsen 2013). Africa's demography is by no means uniform, and some countries and areas have developed distinctive fertility trends. Some countries are living an advanced stage of demographic transition, while others are in the middle of the path. Finally, a few of them are in the first stage of the process. In the Appendix, we reported some demographic indicators of the sub-Saharan region (Table I/App.).

\section{Woman status in sub-Saharan Africa}

The high fertility primarily reflects the universality and the earliness of the wedding (excluding SouthAfrica, in fact, in all other countries people are married in young ages), although the age at first marriage is increasing in many countries, as a manifestation of the demographic transition process. The number of girls married as children will double by 2050 and Africa will become the region with the highest number of child brides in the world. Women married at 15 are $12 \%$ of people of the same age, and $40 \%$ married at I 8 (UNICEF, 20I5).

The behaviors that affect the formation of the family and descendants are also affected by other phenomena typical of the region, including polygamy, still widespread particularly in the center-west, the mirror of a culture influenced by Islam and the traditional religions that lead to observe a patriarchal regime, which is accompanied by the subjugation of women. The adolescent marriage pattern (HRW, 2015) and the high fertility goes together with a low utilization of health care during pregnancies and deliveries, in addition to a marked presence of complications related to maternal reproductive health.

The cultural model that gives husbands the power of reproductive decisions but that puts every economic importance for the growth of children on mothers has been defined as the priority factor of high fertility in sub-Saharan Africa where woman's status is related to low educational level of girls (Kravdal, 2002; Lloyd et al., 2000; Shapiro, 20II). The prestige of the paternity, without a parallel economic importance for the growth of children, makes husbands push to have large families and the number of desired children, even if declining, remains high (Tabutin and Schoumaker, 2004). These cultural and economic factors act on the intermediate variables of fertility: the precocity of the first sexual intercourse, the first marriage, first pregnancy, all of which are caused by discrimination against women. Not surprisingly, countries with the highest TFR show even higher values in teenage fertility, a clear sign of the precocity with which sexual relations begin. The causes are often related to the lack of knowledge and use of family planning methods that remain very low in many African realities. The connection between teen pregnancies and lack of growth of the human capital of women, with the social and economic impact on the development of young women, is obvious if you look at the differences in schooling and education in some countries of the sub-Saharan Africa. In the region, large amounts of illiterate people are observed, especially for girls. These values lead to different dimensions of the human development total and by gender (Human Development Index and Gender Development Index) that are very low.

In sub-Saharan Africa, there is a 10-percentage point gap between girls' and boys' primary school completion rates, and in only seven of the 54 countries in sub-Saharan Africa do girls have a greater than $50 \%$ chance of going to secondary school. Global Campaign for Education (http://www.campaignforeducation.org/docs/reports/ GCE INTERIM Gender Report.pdf) carried out a survey showing that gender stereotypes still prevail in schools, particularly around male and female attitudes. This perpetuates gender inequalities within the education system and society as a whole. It is hardly surprising, then, that nearly two-thirds of the world's illiterate people are women. True gender equality in education - and beyond - remains far from being achieved (Awumbila, 2006).

A very large number of scholars believe that empowering African women is essential to enabling African societies to achieve their potential. After a decade of unprecedented economic growth, African countries are generating more resources to invest in development. To achieve this target, however, Africa needs to make full use of the skills and talents of all its citizens - including its women - to transform its economies and societies. We know that women are more economically active in Africa - as farmers, workers and entrepreneurs - than anywhere else in the world. They are the key to the welfare of their families and the life prospects of their children. They are an important voice in the governance of their communities and their nations. Yet they face an array of barriers that prevent them from playing these roles to their full potential. These barriers to 
women's full participation are fundamentally unfair. However, they are constraints on Africa's achieving its development potential. Bridging the gender gap could yield profound and long-lasting economic returns (Africa Gender Equality Index 2015, in http://www.afdb.org/fileadmin/uploads/afdb/Docume nts/Publications/African_Gender_Equality_Index_20I

\section{5-EN.pdf).}

On this basis, we put together some indicators of woman status in the models with the aims to understand the process of local development. In our approach, the two concepts, demographic window and female empowerment, go together to explain the picture underlined for sub-Saharan Africa.

\section{Data and Methods}

\section{Data sources and countries}

Our analysis is based on harmonized census microdata samples from the Integrated Public Use Microdata Series (IPUMS) International database (Minnesota Population Center, 2010) disseminated via the AICMD portal. IPUMS International is a census micro-data collection that offers data at the individual level that can be aggregated at the level of small areas. Through the census IPUMS we can build measures of health, fertility, infant mortality, characteristics of the household and dwelling, work status, etc. These data allow us to start from the individual census data to analyze the correlation between development and demographic variables placing them in a geographic context characterized by certain socio-economic and cultural aspects. Among the 258 censuses available in the database at the time we started our analyses (corresponding to 79 countries), we focused on those relating to the sub-Saharan African region. After a preliminary examination of the data collected by the censuses, we selected 13 countries (Ghana, Kenya, Liberia, Malawi, Mali, Rwanda, Senegal, Sierra Leone, South Sudan, Sudan, Tanzania, Uganda and Zambia). Figure 2 shows the countries considered in the study. For some countries (Ghana, Malawi, Tanzania, Uganda, and Zambia) we could count on more than one census. Thus, we faced with a total of 19 censuses centered on 1990, 2000 and 2010 that allowed us to totally examine 1359 geographical units at the local level (districts or departments, more generally municipalities).

\section{Fig. 2 - Selected African countries.}

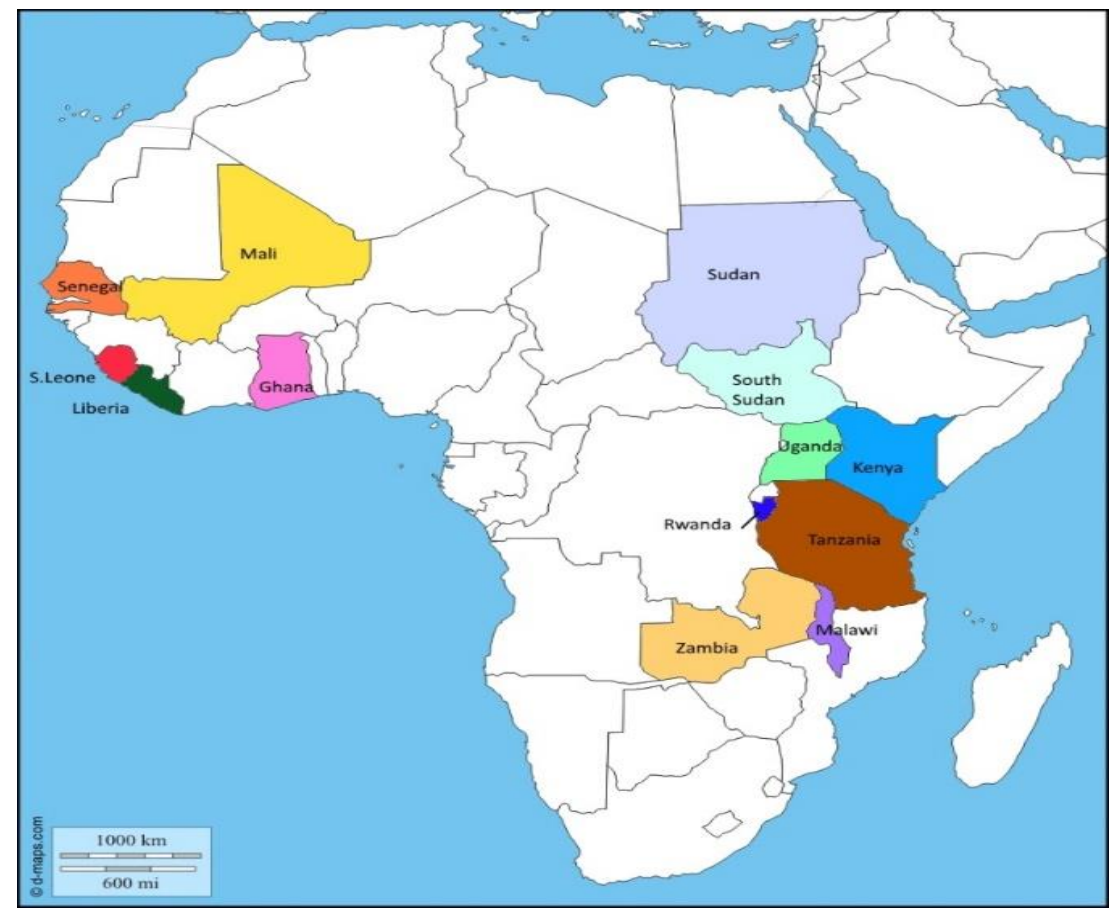

\section{Variables and measures}

Our dependent key variable is a measure of poverty Several methods of aggregation have been suggested to measure poverty. Alkire and Foster (2007) proposed a multidimensional poverty measure using a counting approach. Some researchers have applied this measure to estimate multidimensional poverty in fourteen Sub- Saharan African countries (Batana, 2013) with an index based on four dimensions (assets, health, schooling and empowerment). In this paper we used a related index, that is MHDI, a HDI- 
like measure for small areas (typically municipalities or districts), which is built through a weak modification of variables used in the building of HDI at state level (Permanyer, Esteve-Palos, Garcia, and McCaa, 20I4). The MHDI is a composite index with three components: health $(\mathrm{H}$, proportion surviving of live-born children), education ( $E$, a composite of literacy and primary education completion), and standard of living (W, amenities or assets, such as potable water, waste disposal and electricity).

IPUMS censuses that have been selected (see again Figure 2) permit also to compute structural and woman's status variables, that are assumed to be associated to MHDI. Dependency ratio was used for measuring the demographic pressure. Then we calculated some indices which can represent the level of women' empowerment: the ratio between ever married women and total women aged 15-19 (CONI519); the rate of women who are head of their families among those aged 20-49 (FHH); the female employment rate (EMP), calculated as the ratio between women in employment aged 15-49 and the total of women aged 15-49. Moreover, we calculated the ratio between women aged I5-29 with secondary and tertiary level of schooling and men with the same characteristics (GENEDU) as a measure of the educational gender differences. All these variables were calculated at the municipal level for each country and then properly categorized, in order to control for possible non-linear associations with the dependent variable.

\section{Method}

After a preliminary descriptive analysis of MHDI, we conducted regression multivariate analyses to assess the role played by both the structural and social variables on the HDI. MHDI is our dependent variable, while demographic pressure, female status and gender inequalities are our explanatory variables:

$$
\mathrm{MHDI}=f(\mathrm{ID}, \mathrm{CON} I 5 \mathrm{I}, \mathrm{FHH}, \mathrm{EMP}, \mathrm{GENEDU})
$$

Finally, in the last model, we included also the territorial context (country-timing variable):

MHDI $=f($ ID, CONI5I9, FHH, EMP, GENEDU, COUNTRIES)

The associations between MHDI and covariates were studied using a classical least square multiple regression models and not through a hierarchical or multilevel data structure (where the first-level units are the municipalities and the second-level units are the countries). The reason why we did not adopt this approach is that the 19 selected censuses cannot be considered as a casual sample from a population of countries because some of them refer to same country and the number of countries that we could analyze removing the repeated censuses (13) is not large enough (Snijders and Bosker, 20I2).

According to our hypotheses, the level of development measured by MHDI at district level is associated with the covariates in the following way (in the brackets the sign of the relationship):

\section{ID: Dependency ratio (-);}

GENEDU: Ratio between women aged 15-29 with secondary and tertiary level of schooling and men with the same characteristics $(+)$;

CONI519: Adolescent married, ratio between ever married women and total women aged I5-19(-);

$\mathrm{FHH}$ : Ratio between women 20-49 who are head of their families and the total of women 20-49 (+), a positive sign on the assumption that being the head of a family implies a greater level of autonomy;

EMP: female employment rate, aged I5-49 (+).

\section{The countries: an overview}

The selected countries in the context of subSaharan Africa and the dependency ratio

Three broad groups of countries can be distinguished on the base of the evolution of their age structure: (I) advanced, where the transition is largely complete; (2) ongoing, where the transition is underway; and (3) nascent, where little or no transition has yet taken place. The first group includes the following countries: Mauritius, Seychelles, Cabo Verde, Botswana, South Africa. These countries started their transitions in the 1960s and have nearly completed the process, in roughly the same period as East Asia and Latin America. Their transitions were made feasible by fast declines in mortality and fertility rates. These countries experienced some of the highest GDP growth in subSaharan Africa during their transition, and passed to middle-income status.

The second group includes the largest part of subSaharan Africa, i.e. Namibia, Swaziland, Equatorial Guinea, Kenya, Zimbabwe, Lesotho, Sao Tome, Ghana, Rwanda, Eritrea, Guinea Bissau, Burundi, Togo, Madagascar, Comoros, Gabon, Senegal, Sierra Leone, Benin, Cameroon, Central African Rep., Cote d'Ivoire, Ethiopia, Congo, and Burkina Faso. This group refers to the countries where the transition started during the 1980s, and where the peak share of the working age population will not be reached before 2050. The increase in the share of the working age population varies between 10 percentage points for countries such as Namibia and 
Swaziland, to marginally more than 2 percentage points for countries like Burkina Faso and Republic of Congo. The third group includes Chad, Liberia, Mali, Malawi, Niger, South Sudan and Sudan.

We observe that in the countries we examined belonging to the second and third group cited above, the level of youth dependency ratios is very high (and consequently, represents an obstacle to development) while the old dependency ratios are very low. We report, in Figure 3, the distribution of municipalities according to the level of dependency ratios.

Figure 3 - Distribution of municipalities according to youth and old dependency ratios, selected countries of sub-Saharan Africa.

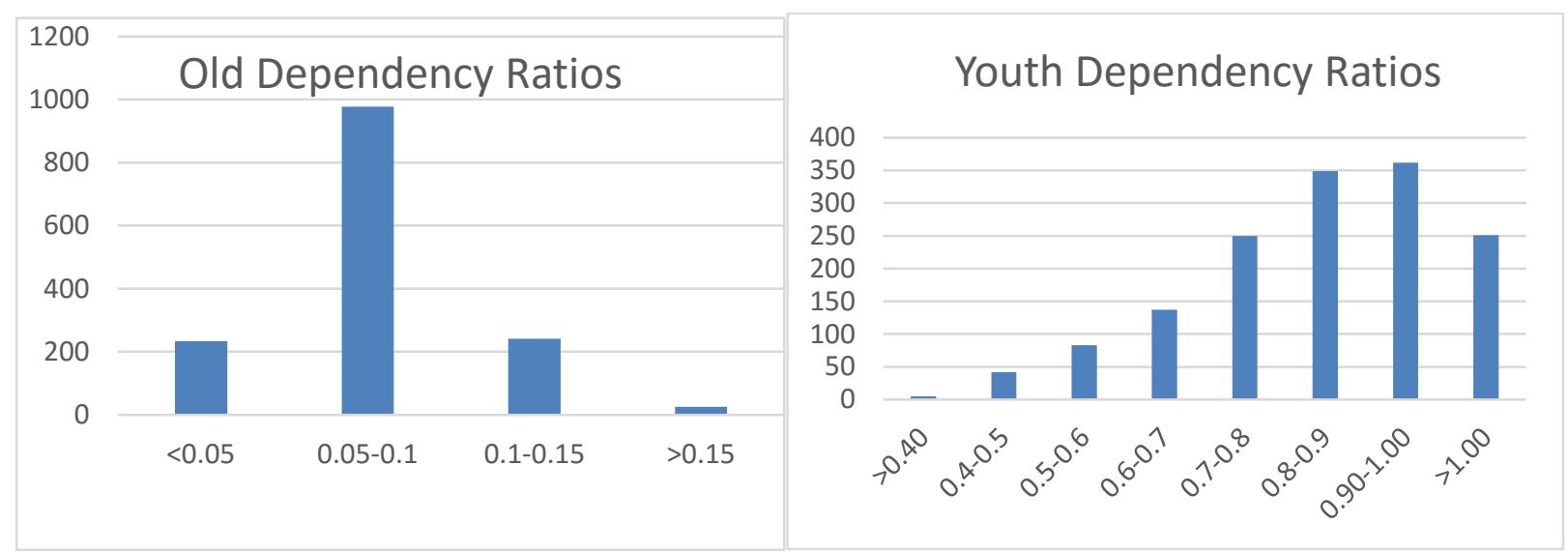

Sources: our elaborations on IPUMS data

MHDI at the national and municipality levels

In table I we report the mean value of MHDI, calculated at municipality level, for the countries belonging to sub-Saharan Africa we focus in this paper. Generally, MHDI increases with time, but there is also a strong difference among countries. The more developed countries in the first decade of $X X I$ century (with a mean value of MHDI higher than 0.6) are Ghana, Tanzania and Zambia. The standard deviation does not naturally explain the differences of the level of development among the municipalities, and we report in the maps below (Figure 4), for two country-examples, Ghana and Tanzania.

Figure 4 also shows that it exists an inverse relationship between the two indicators: where MHDI is higher, ID is lower and vice-versa. The norther municipalities both of Tanzania and Ghana present high value of ID and low value of MHDI, and this confirms, at a descriptive level, that where there is a more favorable social context, the structure of population is characterized by a higher proportion of active age population.

Table I - Mean and standard deviation values of MHDI for some countries of sub-Saharan Africa

\begin{tabular}{|l|c|c|c|}
\hline COUNTRY YEAR & N. districts & Mean & Std. Dev. \\
\hline GHANA_2000 & & & .115509 \\
\hline GHANA_20I0 & 111 & .49412 & .123847 \\
\hline KENYA_1989 & 171 & .63067 & .129507 \\
\hline LIBERIA_2008 & 42 & .59086 & .086574 \\
\hline MALAWI_1998 & 48 & .49344 & .071665 \\
\hline MALAWI_2008 & 27 & .50161 & .094598 \\
\hline MALI_2009 & 32 & $.5928 I$ & .075321 \\
\hline RWANDA_2002 & 48 & .43289 & .064164 \\
\hline SENEGAL_2002 & 13 & .52237 & .078641 \\
\hline SIERRA LEONE 2004 & 35 & .57833 & .109793 \\
\hline SOUTH SUDAN 2008 & 102 & .38658 & .084102 \\
\hline SUDAN 2008 & 74 & .35380 & .159108 \\
\hline TANZANIA 1988 & 130 & .49768 & .087482 \\
\hline TANZANIA 2002 & 114 & .59272 & .083924 \\
\hline
\end{tabular}




\begin{tabular}{|l|l|l|l|} 
UGANDA 1991 & 40 & .47768 & .102881 \\
\hline UGANDA 2002 & 57 & .56210 & .086652 \\
\hline ZAMBIA 1990 & 56 & .55444 & .125439 \\
\hline ZAMBIA_2000 & 73 & .55340 & .112965 \\
\hline ZAMBIA_2010 & 75 & .63631 & .094904 \\
\hline
\end{tabular}

Source: Our elaboration on IPUMS data.

Figure 4 - Municipalities of Tanzania and Ghana according the value of MHDI and ID, quantiles methods (quartiles: increasing values represented by higher intensities).

\section{Tanzania (MHDI)}

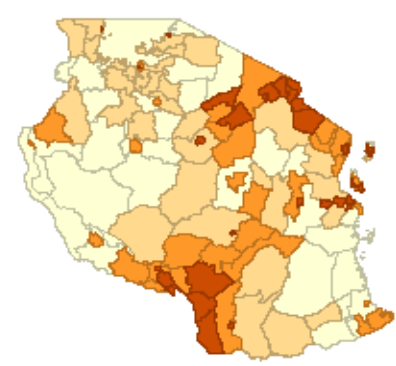

Tanzania (ID)

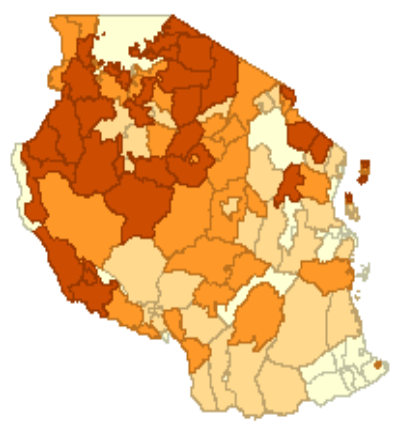

Modelling the association between MHDI and demographic pressure in a gender perspective

Table 2 presents the parameter estimates of a linear regression models aiming to analyze the association between MHDI' and ID (mod.I), woman's status and gender inequalities (mod. 2) and ID plus gender variables (mod.3). Model I, which is carried out on all districts (all countries and years) shows that dependency ratio is negatively related with MHDI. The coefficients are highly significant and this result confirms our hypothesis: the higher the non-active aged people, the lower the development. Model 2 considers only gender and status of women variables, and exactly the proportion of women aged 15-19 already married, the rate of female head of families

\section{Ghana (MHDI)}

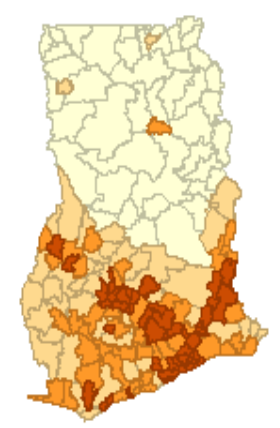

Ghana (ID)

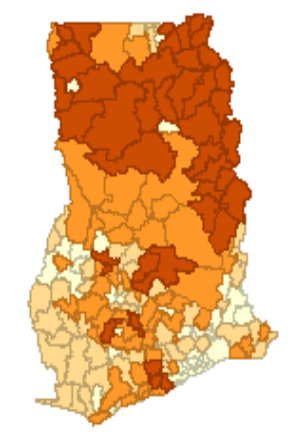

for those aged 20-49, female work condition at age 15-49 (working, not working), and gender differences in secondary and tertiary education among women and men aged 15-29. In addition, the model considers also the interactions between the rates of female employment and female heads of families.

Model 2 greatly improves R-square (from 0.18 to 0.45). The interpretation of the effects of education by gender is very clear: the more educated women are with respect to men, the higher the level of development, meaning that investing in female education represents investing in socio-economic progress. 
On the contrary, the higher the proportion of married young women, the lower development is. Notice that significant negative associations is shown already with rates of adolescent married women greater than a quarter. More intriguing is the results referring $\mathrm{FHH}$ and EMP. Increasing proportions of female-headed families is not significantly correlated with MHDI levels. In addition, contrary to our assumptions, women's labor market participation is negatively correlated with MHDI. However, if we consider the interaction between $\mathrm{FHH}$ and EMP the negative association between MHDI and EMP disappears as female-headed families increase.

Table 2 - Models I, 2 and 3: parameters estimates of least square regression models (dependent variable: MHDI - covariates: ID and variables representing women's empowerment) ${ }^{\mathrm{ii}}$

\begin{tabular}{|c|c|c|c|c|c|c|c|c|c|}
\hline \multirow{2}{*}{ Variables } & \multicolumn{3}{|c|}{ Mod.I } & \multicolumn{3}{|c|}{ Mod.2 } & \multicolumn{3}{|c|}{ Mod.3 } \\
\hline & $\begin{array}{l}\text { Parameter } \\
\text { Estimate }\end{array}$ & $\begin{array}{l}\text { Standard } \\
\text { Error }\end{array}$ & $\operatorname{Pr} \underset{\mid}{>} \mid \mathrm{t}$ & $\begin{array}{c}\text { Parameter } \\
\text { Estimate }\end{array}$ & $\begin{array}{l}\text { Standard } \\
\text { Error }\end{array}$ & $\operatorname{Pr} \underset{\mid}{\mid} \mid \mathrm{t}$ & $\begin{array}{c}\text { Parameter } \\
\text { Estimate }\end{array}$ & $\begin{array}{l}\text { Standard } \\
\text { Error }\end{array}$ & $\operatorname{Pr}>|t|$ \\
\hline Intercept & -0.55816 & 0.03005 & $<.0001$ & 0.54136 & 0.01097 & $<.0001$ & 0.62184 & 0.01209 & $<.0001$ \\
\hline \multicolumn{10}{|l|}{$I D($ ref. $<0.75)$} \\
\hline $0.75-0.90$ & -0.24829 & 0.03611 & $<.0001$ & & & & -0.09144 & 0.00996 & $<.0001$ \\
\hline $0.90+$ & -0.49488 & 0.03237 & $<.0001$ & & & & -0.13313 & 0.00959 & $<.0001$ \\
\hline \multicolumn{10}{|c|}{$\operatorname{CON} 1519($ ref. $<0,26=\mathrm{Me})$} \\
\hline $0.26-0.36=\mathrm{Q} 3$ & & & & -0.07417 & 0.00720 & $<.0001$ & -0.05139 & 0.00696 & $<.0001$ \\
\hline$\geq 0.36$ & & & & -0.11988 & 0.00791 & $<.0001$ & -0.09514 & 0.00766 & $<.0001$ \\
\hline \multicolumn{10}{|c|}{$F H H($ ref. $<0.12=Q I)$} \\
\hline $0.12-0.18=\mathrm{Me}$ & & & & 0,00485 & 0,01290 & 0,7070 & 0.02031 & 0.01212 & 0.0941 \\
\hline$\geq 0.18$ & & & & -0.02361 & 0.01488 & 0.1129 & -0.00759 & 0.01396 & 0.5869 \\
\hline \multicolumn{10}{|c|}{ EMP (ref. $<0.42=Q I)$} \\
\hline $0.42-0.72=\mathrm{Q} 3$ & & & & -0.07225 & 0.01295 & $<.0001$ & -0.05293 & 0.01218 & $<.0001$ \\
\hline$\geq 0.72$ & & & & -0.11226 & 0.01707 & $<.0001$ & $-0.08 \mid 43$ & 0.01611 & $<.0001$ \\
\hline \multicolumn{10}{|c|}{ Interactions $F H H^{*} E M P$} \\
\hline FHHI2*EMPI3 & & & & 0.03611 & 0.01803 & 0.0455 & 0.02798 & 0.01689 & 0.0977 \\
\hline FHHI $2 * E M P 3+$ & & & & 0.05501 & 0.02327 & 0.0182 & 0.03811 & 0.02178 & 0.0804 \\
\hline $\mathrm{FHH} 2+* \mathrm{EMPI} 3$ & & & & 0.09892 & 0.01889 & $<.0001$ & 0.07807 & 0.01772 & $<.0001$ \\
\hline $\mathrm{FHH} 2+*$ EMP3+ & & & & 0.11497 & 0.02221 & $<.0001$ & 0.10118 & 0.02079 & $<.0001$ \\
\hline \multicolumn{10}{|c|}{ GENEDU (ref. $<0.48=Q I)$} \\
\hline $0.48-0.66=\mathrm{Me}$ & & & & 0.06347 & 0.00835 & $<.0001$ & 0.06789 & 0.00781 & $<.0001$ \\
\hline $0.66-0.86=\mathrm{Q} 3$ & & & & 0.09143 & 0.00873 & $<.0001$ & 0.08974 & 0.00817 & $<.0001$ \\
\hline$\geq 0.86$ & & & & 0.11717 & 0.00897 & $<.0001$ & 0.10379 & 0.00844 & $<.0001$ \\
\hline $\begin{array}{l}\text { R-squared } \\
\text { (corrected) }\end{array}$ & \multicolumn{3}{|c|}{$\begin{array}{l}0.1783 \\
(1771) \\
\end{array}$} & \multicolumn{3}{|c|}{$\begin{array}{c}0.4494 \\
(0.444 I)\end{array}$} & \multicolumn{3}{|c|}{$\begin{array}{c}0.5198 \\
(0.5144)\end{array}$} \\
\hline N. of cases & \multicolumn{3}{|c|}{1359} & \multicolumn{3}{|c|}{1359} & \multicolumn{3}{|c|}{1359} \\
\hline
\end{tabular}

Obviously, we cannot automatically link the two results, concluding that the female work is beneficial for a country only in the case in which the women have a relevant role into the family. However, this let 
us suppose that - at least in these countries - the woman's employment might have different meaning depending on the different role played by the women in a society.

Model 3 - that joints covariates of model I and model 2 - confirms all these results. In particular, the role played by the female labor work participation interacts with the proportion of female-headed families: the sign of the coefficients changes passing from a low proportion of female-headed families to a medium and high value. Initially, the sign is negative, expressing that in a context characterized from a few families headed by women and high proportion working women (with respect to reference category low proportion) the level of development tends to decrease. At a later stage, the sign becomes positive. We will discuss this in the next section. Interesting, adding gender covariates, the coefficient associated to the demographic covariate is still statistically significant; thus, demographic pressure seems to play an autonomous role on the development of a country even controlling for covariates (woman's status and gender equity) that more or less directly can influence the demographic pressure.
Lastly, model 4 (table 3) includes also the dummy variables indicating the censuses. In addition, aiming to a more economic model, model 4 presents only significant interactions between $\mathrm{FHH}$ and EMP. The control for the geographical and time contexts does not change significantly the associations found with the previous model, thus suggesting that the effects of the gender and structure covariates are not mediated through the country-timing contexts. It, however, further improves the fitting of the model ( $R$ square is now 0.72 ) and suggests that, with reference to Ghana 2000 - apart some not significant coefficients, maybe related to the weak number of territorial units of some countries - almost all the coefficients are positive, meaning that the global situation of development of the countries is better than the Ghana 2000 one. This is the case, for example, of Tanzania, Uganda e Zambia, with increasing effects in the time. Sierra Leone and South-Sudan are an exception, and the negative coefficient is expressing a worse socio-economic situation with respect to Ghana 2000.

Table 3 - Model 4: Parameter estimates of a least square regression model (dependent variable MHDI; Covariates: ID, women's empowerment variables and country-timing dummies) ${ }^{(5)}$

\begin{tabular}{|c|c|c|c|c|c|c|c|}
\hline Variables & $\begin{array}{l}\text { Parameter } \\
\text { Estimate }\end{array}$ & $\begin{array}{l}\text { Standard } \\
\text { Error }\end{array}$ & $\operatorname{Pr}>|t|$ & Variable & $\begin{array}{c}\text { Parameter } \\
\text { Estimate }\end{array}$ & $\begin{array}{l}\text { Standard } \\
\text { Error }\end{array}$ & $\operatorname{Pr}>|t|$ \\
\hline Intercept & 0.58947 & 0.01308 & $<.0001$ & & & & \\
\hline \multicolumn{8}{|l|}{ ID $($ ref. $<0.75)$} \\
\hline $0.75-0.90$ & -0.09740 & 0.00776 & $<.0001$ & \multicolumn{2}{|c|}{ Country (ref. Ghana_2000) } & & \\
\hline $0.90+$ & -0.14782 & 0.00765 & $<.0001$ & Ghana_2010 & 0.07479 & 0.00949 & $<.0001$ \\
\hline \multicolumn{2}{|c|}{ CONI5/9 (ref. $<0,26=\mathrm{Me}$ ) } & & & Kenya_1989 & 0.08884 & 0.01384 & $<.0001$ \\
\hline $0.26-0.36=\mathrm{Q} 3$ & -0.05605 & 0.00565 & $<.0001$ & Liberia_2008 & 0.02388 & 0.01378 & 0.0833 \\
\hline$\geq 0.36$ & -0.08373 & 0.00666 & $<.0001$ & Malawi_1998 & 0.09074 & 0.01708 & $<.0001$ \\
\hline \multicolumn{2}{|c|}{$F H H($ ref. $<0.12=Q I)$} & & & Malawi_2008 & 0.10224 & 0.01566 & $<.0001$ \\
\hline $0.12-0.18=\mathrm{Me}$ & 0.02455 & 0.00647 & 0.0002 & Mali_2009 & 0.04803 & 0.01526 & 0.0017 \\
\hline$\geq 0.18$ & 0.02837 & 0.01122 & 0.0116 & Rwanda_2002 & -0.02272 & 0.02300 & 0.3234 \\
\hline \multicolumn{2}{|c|}{ EMP (ref. $<0.42=Q I)$} & & & Senegal_2002 & 0.14457 & 0.01708 & $<.0001$ \\
\hline $0.42-0.72=\mathrm{Q} 3$ & -0.03336 & 0.00825 & $<.0001$ & SierraL_200404 & -0.02843 & 0.01179 & 0.0160 \\
\hline$\geq 0.72$ & -0.05536 & 0.01122 & $<.0001$ & S.Sudan_2008 & -0.10937 & 0.01170 & $<.0001$ \\
\hline \multicolumn{2}{|c|}{ Interactions $F H H^{*} E M P$} & & & Sudan_2008 & -0.01020 & 0.01269 & 0.4220 \\
\hline $\mathrm{FHH} 2+* \mathrm{EMP} \mid 3$ & $0.037 / 2$ & 0.01228 & 0.0025 & Tanzania_1988 & 0.12812 & 0.01052 & $<.0001$ \\
\hline $\begin{array}{l}\mathrm{FHH} 2+ \\
\text { *EMP3+ }\end{array}$ & 0.03315 & 0.01401 & 0.0181 & Tanzania_2002 & 0.09692 & 0.01056 & $<.0001$ \\
\hline
\end{tabular}




\begin{tabular}{|c|c|c|c|c|c|c|c|}
\hline Variables & $\begin{array}{l}\text { Parameter } \\
\text { Estimate }\end{array}$ & $\begin{array}{l}\text { Standard } \\
\text { Error }\end{array}$ & $\operatorname{Pr}>|t|$ & Variable & $\begin{array}{l}\text { Parameter } \\
\text { Estimate }\end{array}$ & $\begin{array}{l}\text { Standard } \\
\text { Error }\end{array}$ & $\operatorname{Pr}>|t|$ \\
\hline \multicolumn{2}{|c|}{ GENEDU (ref. $<0.48=Q \mathrm{Q}$ ) } & & & Uganda_1991 & 0.07761 & 0.01506 & $<.0001$ \\
\hline $0.48-0.66=\mathrm{Me}$ & 0.03694 & 0.00635 & $<.0001$ & Uganda_2002 & 0.1289 & 0.01324 & $<.0001$ \\
\hline $0.66-0.86=Q^{3}$ & 0.05448 & 0.00687 & $<.0001$ & Zambia_1990 & 0.06155 & 0.01477 & $<.0001$ \\
\hline \multirow[t]{2}{*}{$\geq 0.86$} & 0.08318 & 0.00749 & $<.0001$ & Zambia_2000 & 0.12279 & 0.01242 & $<.0001$ \\
\hline & & & & Zambia_2010 & 0.12876 & 0.01254 & $<.0001$ \\
\hline N. cases & 1359 & & & & & & \\
\hline $\begin{array}{l}\text { R squared } \\
\text { (corrected) }\end{array}$ & $\begin{array}{c}0.7230 \\
(0.7165)\end{array}$ & & & & & & \\
\hline
\end{tabular}

\section{Discussion}

The demographic window that some of the developing countries are currently entering offers a unique chance for economic growth. For a restricted number of years, the size of the working age population is at its maximum compared to the size of the dependent population and hence a high productive capacity goes together with low caring costs for the young and the old. To make optimal use of this demographic bonus it is important to gain insight into the circumstances under which this favorable demographic situation is associated with the largest economic growth. During the period of demographic window some conditions must therefore occur, in particular investment on human capital and women's empowerment. We must underline that the largest group of countries in subSaharan Africa has not reached the stage of demographic transition that corresponds, by a structural point of view, to demographic window. Many of the countries are far from this moment, and the high level of fertility leads to observe a high value of dependency ratio, i.e. of demographic pressure.

This study enriches the literature by exploring the effect of the demographic pressure on economic growth at municipality level within some countries of sub-Saharan Africa, in relationship with some indicators of gender equality as proxy of women's empowerment. Using a relatively large number of territorial units (municipality), our results demonstrate a positive effect on development of the active population even if controlling for women empowerment. Thus, the decline of demographic pressure, and the approach to demographic window, seem to represent an opportunity of development.

According to Minh (20/2) that has carried out a research based on data from the World Bank and using a sample of forty-three developing economies, a fall in the fertility rate first causes a decline in the overall dependency ratio, which will be followed by an increase as population ageing sets in. As a result, he deduces that the growth rate of per capita GDP is strongly correlated with both the young and old dependency ratios. Consequently for developing countries that experience a recent decline in the total fertility rate, dependency ratio is reduced, while for those countries who have gone through this decline for a long time, their dependency ratio is increased and hence will experience slower economic growth. In this approach, we find similar results analyzing some countries of sub-Saharan countries. Kogel (2005) finds empirical evidence in cross-country data for the thesis that the youth dependency ratio reduces growth, as it concerns total factor productivity. For this reason, the paper demonstrates that age structure has an effect on the most important determinant of international differences in output per worker. Finally, a focus on experience of Cameroon shows similar results, that is a negative relation between young age structure and development. The past evolution of the age structure is characterized by a demographic malus generated by an increased economic dependency of the nonworking population on the working population, with the corollary growth of social investment needs to the disadvantage of wealth-creating economic investments. Despite acknowledged efforts, the economic and social response of the state was not equal to the needs inherent in the change in age structure. In 1998, nearly one child out of three between 6 and 14 years was not provided with education, nearly one person out of three was unemployed, and $64 \%$ of the children from 12 to 23 months were not completely vaccinated (Beninguissé and Koné, 2005).

Literature confirms also a positive effect of indices of women's empowerment, such as gender equality in education and decline of proportion of married adolescents (Kravdal, 2002; Lloyd et al., 2000; Shapiro, 20I I). It seems instead more complex the interpretation of the role of other variables, such as 
the proportion of female-headed families or the proportion of working women. We interpret this result underlining how the dominant variable is the female-headed proportion of families, joined with the difficult understanding of work in developing countries (Diamond-Smith et al., 20/5). On this last point, it will be necessary to deepen the analysis, because literature is contradictory in this respect. Probably, it depends on the characteristics of labor in developing countries, often referring to informal sectors, and of the relationship with the female headship of households, due to different reasons, such as widowhood, male migration, and so on.

Our reflections conclude stressing the importance of the decline of demographic pressure, if there are policy interventions at local level. The valorization of human capital and in particular the diffusion of education of girls that leads to a delay in age at marriage, and consequently in the age at first birth, appears as the main road to development in those countries that are still living demographic transition. The relationship between female empowerment, decrease of fertility, demographic transition and the approaching of demographic window is the core of the development process.

We must not forget some limitation of our research, firstly the inadequacy of some variables, i.e. female work status that does not take into account the weakness of the women's role in the labor market, often characterized from informal sectors. In addition, development variables we used to calculate MHDI are relatively poor, and this is due to the scarcity of economic and social variables included in the Censuses collected in IPUMS database. The need to dispose of a certain number of countries has obliged to choose variables generally available. Finally, considering a variable referring to country-timing is an attempt to take into account the geographic and temporal context, but it may be that in the future the availability of a larger number of Censuses permits to adopt a hierarchic multilevel approach.

Nevertheless, the results seem clearly to suggest that policy must consider interventions at a local level regarding both the valorization of human capital and women's empowerment. Services must be improved, including maternal and child health services, and family planning programs. Education, in particular for females, must be spread on the whole territory and labor market must be restructured, taking into account also female occupation aiming to the decline of fertility and of infant mortality and, consequently, of the young dependency ratio.

\section{References}

Agwanda A. and Amani $\mathrm{H}, 20 \mathrm{I}$, Population growth, structure and momentum in Tanzania, THDR
2014: Background Paper No. 7, ESRF Discussion Paper 6I, The Economic and Social Research Foundation (ESRF), in www.esrftz.org.

Alkire S., Foster, J.E., 2007, Counting and Multidimensional Poverty Measurement. Oxford Poverty \& Human Development Initiative OPHI Working Paper 7.

Awumbila M., 2006,Gender equality and poverty in Ghana: implications for poverty reduction strategies, GeoJournal 67, 2, pp. |49-|6|.

Batana Y. M., 2013, Multidimensional Measurement of Poverty among Women in sub-Saharan Africa, Social Indicators Research, I 12, pp. 337-362.

Beninguissé g. and Koné H., (2005), Change in Age Structure and Development in Cameroon, in http://www.cicred.org/Eng/Publications/pdf/AgeSt ructural_05-BeninguisseKone-Engl.pdf

Bloom D., Canning E. and Malaney P. N. 2000, "Population dynamics and economic growth in Asia," Population and Development Review 26: 257-290.

Bloom, D.E., Canning, D. and Sevilla, J., 2003, The demographic dividend. A new perspective on the economic consequences of population change, Santa Monica, RAND Monograph Report, RAND Corporation.

Bongaarts J., 2009, Human population growth and the demographic transition, Philos Trans R Soc Lond B Biol Sci. 2009 Oct 27; 364(I532): 29852990.

Bongaarts J. and Casterline J., 2013, Fertility Transition: Is sub-Saharan Africa Different? Popul Dev Rev. Popul Dev Rev. 2013 Feb; 38 (Suppl I): 153-168.

Caldwell, J. and Caldwell, P., 1993, The South African fertility decline, in "Population and Development Review», n. 19, 2, pp. 225-262.

Diamond-Smith N., Bishai D. and El Gibaly O., 20I5, Inter-generational co-residence and women's work and leisure time in Egypt, Demographic Research, vol. 33, 31, pp. 909-938, in http://www.demographicresearch.org/volumes/vol33/31/33-31.pdf.

Duflo E., 20I2, Women Empowerment and Economic Development, Journal of Economic Literature 2012, 50(4), $105 \mid-1079$, in http://economics.mit.edu/files/74I 7.

Ebenstein A, 2014, Fertility and Population in Developing Countries, Encyclopedia of Health Economics, pp. 300-308.

Ekane D., 2013, Fertility trends in sub Saharan Africa, in http://www.divaportal.org/smash/get/diva2:602495/FULLTEXTOI. pdf.

Golini A., 2004, Globalization, Demographic trends and human Mobility, Proceedings of the XLII 
Scientific Meeting of Italian Statistical Society, Plenary Session, Bari, CLEP.

Haghshenas N. M., Sayyadi A., Taherianfard S., and Salehi N., 2007, Population Dynamics and Human Development Indices in selected African countries: Trends and Levels, Submitted to UAPS $5^{\text {th }}$ Population Conference, Arusha, Tanzania, I014 december.

Hammer, B., Prskawetz A., and Freund I., 20I5, "Production activities and economic dependency by age and gender in Europe: A cross-country comparison," The Journal of the Economics of Ageing 5: 86-97.

Human Rights Watch, 2015, Ending Child Marriage in Africa, Opening the Door for Girls' Education, Health, and Freedom from Violence, in https://www.hrw.org/news/2015//2/09/endingchild-marriage-africa.

Kögel T., (2005) Youth dependency and total factor productivity, Journal of Development Economics Volume 76, Issue I, pp. 147-I73.

Kravdal, Ø., 2002, Education and fertility in subSaharan Africa: Individual and community effects, Demography, n. 39, 2, pp. 233- 250.

Livi Bacci M., 20/4, Fine della demografia? L'agenda post-20I5 per lo sviluppo sostenibile, Rivista II Mulino" $\mathrm{n}$.

$4 / 14$, http://www.rivistailmulino.it/journal/articlefulltext/ index/ Article/Journal:RWARTICLE:7735I.

Lloyd, C.B., Kaufman, C.E. and Hewett, P., 2000, The spread of primary school in sub-Saharan Africa: Implications for fertility change, Population and Development Review, n. 26, 3, pp. 483-5I5.

Lutz, W., Sanderson W.C., and Scherbov S., 2008, "The coming acceleration of global population ageing," Nature 45I: 716-719.

Madsen E. L., 2013, Why Has the Demographic Transition Stalled in Sub-Saharan Africa? In https://www.newsecuritybeat.org/2013/08/demog raphic-transition-stalled-sub-saharan-africa/.

Madsen E.L., Daumerie B. and Hardee K., 20I2, The Effects of Age Structure on Development - Policy Aand Issue Brief in http://pai.org/wpcontent/uploads/20I2/0I/SOTC_PIB.pdf.

Minh Quang Dao, Population And Economic Growth In Developing Countries, International Journal of Academic Research in Business and Social Sciences January 2012, Vol. 2, No. I www.hrmars.com/journals

Nugent R. and Barbara Seligman B., 2008, How Demographic Change Affects Development, in http://www.cgdev.org/doc/Demographic_and_De velopment/DD_background_12_10_08.PDF).

OAU and ECA, 20I0, Population and Development in Africa, A Briefing Note Prepared by Organization of African, Unity (OAU) and
Economic Commission for Africa (ECA), in http://www.un.org/popin/icpd/conference/bkg/po p.html.

OECD, 201I, Women's economic empowerment, Issues paper, DAC Network on Gender equality, in www.oecd.org/dac/gender.

OECD, 2012, Women's economic empowerment. Promoting pro-poor growth: the role of empowerment, https://www.oecd.org/dac/povertyreduction/50I5 7530.pdf.

Permanyer I., Esteve-Palos A., Garcia J., and McCaa R., 2014, Human Development Index-like Small Area Estimates for Africa computed from IPUMSInternational integrated census microdata, Paper present at the EPC Conference, Budapest.

Permanyer I., 2013, Using census data to explore the spatial distribution of human development, World Development, 10.1016/j.worlddev.2012.11.015.

Rodríguez-Pose A. and Tijmstra S., 2005, Local Economic Development as an alternative approach to economic development in SubSaharan Africa, Report for the World Bank, Paper adapted from that prepared for the World BankNetherlands Partnership Program Evaluating and Disseminating Experiences in Local Economic Development (LED), http://siteresources.worldbank.org/INTLED/ Resources/339650|| 440997|89|4/AltOverview.pdf

Roy S. K. and Roy S., 2014, Demographic dividend in India: a synoptic view, International Journal of Business and Administration Research Review, vol. 2, 4, pp. I66-I75.

Sanderson W.C. and Scherbov S., 2015, Are We Overly Dependent on Conventional Dependency Ratios? Population and Development Review, Volume 4I, Issue 4, pages 687-708, December 2015

Saritha K. and Chandrashekara B., 20I4, Regional Variation in Population Ageing and Human Development in Karnataka, e-Library Science Research Journal, vol. 2, 9.

Shapiro D., 20II, Women's Education and Fertility Transition in Sub-Saharan Africa, Paper prepared for presentation at the Wittgenstein Centre Conference on Education and the Global Fertility Transition, Vienna,

http://econ.la.psu.edu/peopledocuments/d89/David\%20Shapiro\%20\%20Womens\%20Education\%20and\%20Fertility \%20Transition\%20in\%20SubSaharan\%20Africa\%20\%200ct\%20\%20\%20I I.pdf 
Snijders T. A. B and Bosker R. J., 2012, Multilevel analysis. An introduction to basic and advanced multilevel modeling, Sage, London

Swartz S., 2012, Decentralization, local development and women's empowerment: Innovating knowledge and practice, Editorial Universitas Forum, vol. 3, no. I, in http://hdrnet.org/638/2/Decentralization\%2C_Lo cal_Development_and_Women\%E2\%80\%99s_E mpowerment_Innovating_Knowledge_and_Practi ce.pdf.

Tabutin, D. and Schoumaker, B., 2004, The demography of sub-Saharan Africa from the 1950s to the 2000s. A survey of changes and a statistical assessment, Population, n. 59, 3-4, pp. 457-556.

Wakeman-Linn J., Anand R., Drummon P., Erlebach R., Roc F. , Thakoor V., and Treviñ J., 2015, How Can Sub-Saharan Africa Harness the Demographic Dividend, https://www.imf.org/external/pubs/ft/reo/20I5/afr Leng/pdf/chap2.pdf.

van der Ven R. and Smits J., 20II, The demographic window of opportunity: age structure and subnational economic growth in developing countries, Nijmegen Center for Economics (NiCE) Working Paper II-102, April 20II.

\section{Appendix}

Table I/App. - Demographic indicators of the countries in sub-Saharan Africa, 20 I0-20I5, estimates.

\begin{tabular}{|l|c|c|c|l|c|c|c|}
\hline \multicolumn{1}{|c|}{ Countries } & TFR & IMR & MAC & & TFR & IMR & MAC \\
\hline Sub-Saharan Africa & 5.10 & 64 & 29.2 & Congo & 4.95 & 5 I & 28.5 \\
\hline Eastern Africa & 4.94 & 53 & 29.1 & Dem. Republic of the Congo & 6.15 & 73 & 29.6 \\
\hline Burundi & 6.08 & 78 & 30.7 & Equatorial Guinea & 4.97 & 70 & 29.0 \\
\hline Comoros & 4.60 & 58 & 30.1 & Gabon & 4.00 & 43 & 28.7 \\
\hline Djibouti & 3.30 & 55 & 32.1 & Sao Tome and Principe & 4.67 & 44 & 29.7 \\
\hline Eritrea & 4.40 & 46 & 29.7 & Southern Africa & 2.5 I & 40 & 28.1 \\
\hline Ethiopia & 4.59 & 50 & 29.9 & Botswana & 2.90 & 32 & 29.8 \\
\hline Kenya & 4.44 & 52 & 28.8 & Lesotho & 3.26 & 60 & 28.0 \\
\hline Madagascar & 4.50 & 37 & 28.1 & Namibia & 3.60 & 34 & 28.9 \\
\hline Malawi & 5.25 & 60 & 28.9 & South Africa & 2.40 & 38 & 28.0 \\
\hline Mauritius & 1.50 & 12 & 27.8 & Swaziland & 3.36 & 65 & 28.0 \\
\hline Mayotte & 4.10 & 4 & 29.8 & Western Africa & 5.54 & 71 & 29.5 \\
\hline Mozambique & 5.45 & 64 & 29.0 & Benin & 4.89 & 69 & 29.0 \\
\hline Réunion & 2.24 & 4 & 28.5 & Burkina Faso & 5.65 & 67 & 29.4 \\
\hline Rwanda & 4.05 & 49 & 30.3 & Cabo Verde & 2.37 & 20 & 27.6 \\
\hline Seychelles & 2.33 & 10 & 27.4 & Côte d'lvoire & 5.10 & 73 & 29.0 \\
\hline Somalia & 6.61 & 79 & 30.1 & Gambia & 5.78 & 47 & 29.7 \\
\hline South Sudan & 5.15 & 78 & 29.8 & Ghana & 4.25 & 51 & 29.8 \\
\hline Uganda & 5.91 & 61 & 28.3 & Guinea & 5.13 & 59 & 29.1 \\
\hline United Rep. of Tanzania & 5.24 & 37 & 28.4 & Guinea-Bissau & 4.95 & 92 & 29.3 \\
\hline Zambia & 5.45 & 55 & 29.0 & Liberia & 4.83 & 61 & 28.9 \\
\hline Zimbabwe & 4.02 & 48 & 28.0 & Mali & 6.35 & 84 & 29.0 \\
\hline Middle Africa & 5.82 & 79 & 28.9 & Mauritania & 4.69 & 67 & 30.5 \\
\hline Angola & 6.20 & 96 & 27.6 & Niger & 4.73 & 60 & 29.1 \\
\hline Cameroon & 4.81 & 74 & 28.6 & Nigeria & 46 & 29.8 \\
\hline Central African Republic & 4.41 & 93 & 29.8 & Senegal & 94 & 29.9 \\
\hline Chad & 6.31 & 96 & 28.0 & Sierra Leone & 50 & 29.2 \\
\hline & & & & Togo & & \\
\hline
\end{tabular}

Source: World Population Prospects, 2015, in https://esa.un.org/unpd/wpp/Download/Standard / 
i Preliminary analyses using as dependent variable $\ln (\mathrm{MHDI})$ in order to control for possible skewness of the distribution, show the same relationships.

ii $I D=$ dependency ratio; CON I519: ratio between ever married women 15-19 and total women 15-19; FHH: ratio between women 20-49 head of a family and women 2049; EMP: female employment rate 15-49; GENEDU: ratio between women 15-29 with secondary and tertiary education and men with same characteristics.

$\mathrm{Q} I=$ first quartile, $\mathrm{Me}=\mathrm{Q} 2=$ median, $\mathrm{Q} 3=$ third quartile. $\mathrm{FHHI}: \mathrm{QI} \leq \mathrm{FHH} \leq \mathrm{Q} 2 ; \quad \mathrm{FHH} 2+: \mathrm{FHH}>\mathrm{Me}$ 